\title{
Handbook of Florida Water Regulation: Emergency Planning and Community Right-to-Know Act ${ }^{1}$
}

\author{
Michael T. Olexa, Luke D'Isernia, Laura Minton, Dulcy Miller, and Sarah Corbett ${ }^{2}$
}

\section{Preface}

This handbook is designed to provide an accurate, current, and authoritative summary of the principle Federal and Florida laws that directly or indirectly relate to agriculture. This handbook should provide a basic overview of the many rights and responsibilities that farmers and farmland owners have under both Federal and Florida laws as well as the appropriate contact information to obtain more detailed information. However, the reader should be aware that because the laws, administrative rulings, and court decisions on which this handbook is based are subject to constant revision, portions of this publication could become outdated at anytime. Several details of cited laws are also left out due to space limitations.

This handbook is distributed with the understanding that the authors are not engaged in rendering legal or other professional advice, and the information contained herein should not be regarded as a substitute for professional advice. This handbook is not all inclusive in providing information to achieve compliance with the Federal and Florida laws and regulations governing water protection. For these reasons, the use of these materials by any person constitutes an agreement to hold harmless the authors, the Florida Cooperative Extension Service, the Institute of Food and Agricultural Sciences, and the University of Florida for any liability claims, damages, or expenses that may be incurred by any person as a result of reference to or reliance on the information contained in this handbook.

\section{Overview}

The Emergency Planning and Community Right-to-Know Act (EPCRA), also known as Title III of the Superfund Amendments and Reauthorization Act (SARA), was passed in 1986 as part of SARA. EPCRA was passed in response to concerns about the environmental and safety hazards posed by the storage and handling of toxic chemicals, hazardous chemicals, and extremely hazardous substances.

EPCRA establishes requirements for federal, state, and local governments, Native American tribes,

1. This is EDIS document FE586, a publication of the Food and Resource Economics Department, Florida Cooperative Extension Service, Institute of Food and Agricultural Sciences, University of Florida, Gainesville, FL. Published December 2005. Please visit the EDIS website at http://edis.ifas.ufl.edu.

2. Michael T. Olexa, Professor, Food and Resource Economics Department, Florida Cooperative Extension Service, Institute of Food and Agricultural Sciences, University of Florida, Gainesville, FL; Director, Agricultural Law Center, University of Florida, Gainesville, FL; and Chair, Agricultural Law Committee of The Florida Bar. Luke D'Isernia, former student (graduated cum laude in 2005), Levin College of Law, University of Florida, Gainesville, FL. Laura Minton, Attorney, Dean, Mead, Egerton, Bloodworth, Capouano, and Bozarth, Orlando, FL. Dulcy Miller, attorney, Foley and Lardner, LLP, Orlando, FL. Sarah Corbett, Attorney, Florida Second District Court of Appeal, Lakeland, FL.

The Institute of Food and Agricultural Sciences (IFAS) is an Equal Opportunity Institution authorized to provide research, educational information and other services only to individuals and institutions that function with non-discrimination with respect to race, creed, color, religion, age, disability, sex, sexual orientation, marital status, national origin, political opinions or affiliations. U.S. Department of Agriculture, Cooperative Extension Service, University of Florida, IFAS, Florida A. \& M. University Cooperative Extension Program, and Boards of County Commissioners Cooperating. Larry Arrington, Dean 
and chemical facilities regarding emergency planning for releases/spills of toxic chemicals, hazardous chemicals, or extremely hazardous substances, and community right-to-know reporting on toxic chemicals, hazardous chemicals and extremely hazardous substances. EPCRA's right-to-know provisions are designed to help increase the public's knowledge and access to information on chemicals at local facilities, their uses, and releases into the environment. Using this information, states, communities, and chemical facilities can improve chemical safety, and protect public health, safety, and the environment from chemical hazards. While EPCRA establishes general requirements for states to follow, it mandates that the states themselves must set the specific categories and requirements by which chemical facilities in those states will be regulated under EPCRA, by enacting state versions of EPCRA. These versions supplement EPCRA, and can be even more stringent. Landowners should consult their state's version of EPCRA. Florida's version of EPCRA is known as the Florida Emergency Planning and Community Right-to-Know Act (FEPCRA).

\section{Who Enforces the EPCRA?}

While the EPA is the primary enforcer of the EPCRA, state governors and/or SARCs are the primary enforcers of their own state's version of EPCRA. In Florida, it is the Florida State Hazardous Materials Emergency Response Commission (FSHMERC), acting on behalf of the Governor, and the Florida Department of Community Affairs (FDCA) that enforce FEPCRA. However, according to FEPCRA, FSHMERC and FDCA cannot bring an action against a violator of a requirement of FEPCRA if the EPA has brought and is pursuing an administrative order or civil penalty to enforce, or imposing a civil penalty for a violation of, the same requirement under EPCRA.

\section{What Facilities Are Covered by EPCRA?}

EPCRA regulates facilities that produce and/or store extremely hazardous substances and toxic or hazardous chemicals above the threshold amounts as listed and determined by the EPA. These facilities must notify the appropriate state officials, identified by EPCRA, that they are covered by EPCRA. For a complete list of chemicals listed as extremely hazardous substances, toxic chemicals, or hazardous chemicals and their threshold storage amounts, please consult the EPA.

\section{What Does EPCRA Require?}

EPCRA has five major provisions:

1. Emergency planning.

2. Submission of Material Safety Data Sheets.

3. Hazardous chemical inventory reporting requirement.

4. Toxic chemical release inventory.

5. Emergency release notification.

Under its emergency planning provision, EPCRA mandated that the governor of each state appoint a state emergency response commission (SERC) no later than six months after October 17, 1986. If a governor failed to appoint such a commission, then that governor would act as the commission until the governor appointed such a commission. SERCs may be made up of one or more existing state-supported or appointed emergency response organizations, and should be comprised of people with expertise in emergency response to the extent possible. Each SERC then had nine months after October 17, 1986 to designate emergency planning districts, existing political subdivisions (counties) where appropriate to facilitate the preparation and implementation of emergency plans. Thirty days after designating emergency planning districts, or 10 months after October 17, 1986, whichever was earlier, each SERC was to appoint a local emergency planning committee (LEPC) for each district. LEPC membership must include local officials, including police, fire, civil defense, public health, transportation, and environmental professionals, as well as representatives of the facilities subject to the emergency planning requirements and the media. It is the responsibility of each LEPC to develop its district's emergency response plan, review it annually along with the SERC and regional response teams, and provide 
information about the emergency response plan and chemicals in the community to citizens in the district.

Required elements of a district emergency response plan include:

- Identify facilities and transportation routes of extremely hazardous substances.

- Describe emergency response procedures, on and off site.

- Designate a community emergency coordinator and facility coordinator(s) to implement the plan.

- Describe how to determine the probable affected area and population by releases.

- Outline evacuation plans.

For the complete list of requirements, please consult the EPA.

EPCRA also imposes several reporting requirements on the owners or operators of the facilities covered by the Act. Owners or operators of these facilities must submit, Material Safety Data Sheets (for each chemical), a hazardous chemical inventory form, and a toxic chemical release inventory form of all the extremely hazardous substances and toxic or hazardous chemicals that the facilities have produced and are storing, to each of the following:

- The appropriate LEPC.

- The SERC.

- The fire department with jurisdiction over the facility.

For a complete list of what should be included in each of these reports, please consult the EPA, FSHMERC, or the FDCA.

If there is a release/spill of a pound or more of any extremely hazardous substance or toxic or hazardous chemical at a facility, the owners or operators of that facility must provide an emergency notification to the community emergency coordinator of the LEPC of the district in which the facility is located. If the release/spill occurred during transportation or storage incident to transportation, the emergency notification requirement will be satisfied by dialing 911 .

The emergency notification must contain the following:

- The chemical name of any substance released.

- An indication of whether the substance is extremely hazardous.

- An estimate of the quantity released into the environment.

- The time and duration of the release.

- Whether the release occurred into air, water, and/or land.

- Any known or anticipated acute or chronic health risks associated with the emergency, and where necessary, advice regarding medical attention for exposed individuals.

- Proper precautions, such as evacuation or sheltering in place.

- Name and telephone number of contact person.

A written follow-up notice must be submitted to the SERC and LEPC as soon as practicable after the release. The follow-up notice must update information included in the initial notice and provide information on actual response actions taken and advice regarding medical attention necessary for citizens exposed.

\section{What Does FEPCRA Require?}

FEPCRA requires that these reporting requirements apply to facilities in both the manufacturing and the non-manufacturing sectors in and to governmental bodies of Florida.

It also requires that the owners or operators of facilities in Florida that are covered by EPCRA must pay several fees, including an annual registration fee, to FSHMERC. The registration fee ranges from \$25 
to $\$ 2000$, and is based on the number of employees employed in Florida at facilities under common ownership or control of the owners or operators according to the How-to-Comply Manual at http://www.floridadisaster.org/cps/SERC/htc1.htm.

Owners or operators of facilities that are required under EPCRA to notify FSHMERC must also pay a one-time filing fee of $\$ 50$. Owners or operators of facilities that are required under EPCRA to submit a Toxic Chemical Release Form must pay an annual reporting fee of up to $\$ 150$.

For a complete list of the fees required under FEPCRA, please consult FSHMERC or the FDCA.

All fees required by FEPCRA are used to support and maintain the FEPCRA institutions across Florida.

\section{What Are the Penalties?}

Under EPCRA, an owner or operator of a facility covered by EPCRA who fails to notify the appropriate state officials, identified by EPCRA, that they are covered by EPCRA can be assessed by the EPA with a civil penalty of up to $\$ 25,000$ for each day that the violation occurs or continues.

A civil penalty of $\$ 25,000$ may be assessed by the EPA for each violation of any of the requirements of or for emergency notification of a release.

Also under EPCRA, any person who knowingly and willfully fails to provide emergency notification of a release can face a fine of up to $\$ 25,000$ and/or a criminal penalty of up to a two-year imprisonment. In the case of a second or subsequent conviction, the violator can face a fine of up to $\$ 50,000$ and/or a criminal penalty of up to a five-year imprisonment.

EPCRA also provides for limited citizen suits against violators of EPCRA.

Under FEPCRA, any owner or operator of a facility, an employer or any other person who knowingly or recklessly provides false written information to be provided pursuant to EPCRA or FEPCRA to FSHMERC, FDCA, or a fire department is liable for a civil penalty of $\$ 5,000$ for each item of false information that is submitted.
Also under FEPCRA, any person who knowingly and willfully provides false information or causes such information to be provided pursuant to EPCRA or FEPCRA to FSHMERC, FDCA, or a fire department in writing, with the intent to mislead FSHMERC, FDCA, or fire department will be guilty of a third-degree felony punishable by a criminal penalty of up to five-years imprisonment and/or a fine of $\$ 5,000$.

FEPCRA also states that any provision of EPCRA which creates a federal cause of action will also create a corresponding cause of action under Florida state law, with jurisdiction in the circuit courts. Furthermore, any provision of EPCRA which imposes or authorizes the EPA to impose a civil penalty will also impose or authorize the imposition of a civil penalty by the Florida Department of Community Affairs (FDCA), with jurisdiction in the county where the violation occurred or where the defendant has its principal place of business.

While this may sound like a violator of EPCRA will face penalties under both EPCRA and FEPCRA, it is important to note that, according to FEPCRA, an action cannot be brought against a violator of a requirement of FEPCRA if the EPA has brought and is pursuing an administrative order or civil penalty to enforce, or imposing a civil penalty for a violation of, the same requirement under EPCRA.

\section{Source}

42 United States Code, Sections 11001 to 11050 ; Chapter 252, Florida Statutes, Sections 252.81 to 252.90

\section{Acknowledgments}

The authors are indebted to the personnel of both state and federal agencies who provided their time and advice in the preparation of this handbook. The authors are especially indebted to Richard Budell of the Office of Agricultural Water Policy of the Florida Department of Agriculture and Consumer Services for providing funds for the development of this publication. 